\title{
Manajemen Pembelajaran Pendidikan Agama Islam Berbasis Inklusi bagi Anak Disabilitas di Kota Makassar
}

\author{
Rd. Zaky Miftahul Fasa \\ STIE Tri Dharma Nusantara Makassar \\ zakymiftahulfasa@gmail.com
}

\begin{abstract}
Inclusive education, especially in the Islamic education (PAI) subject, is a guaranteed concept for citizens to get their right for education without exception. This study aims to determine how inclusion-based PAI learning management for children with disabilities in Makassar City uses qualitative methods and uses observation, interview and documentation study techniques. There are four findings in this study, namely: (1) learning planning has been prepared by Islamic Education teachers based on the curriculum of 2013 and adapted to the characteristics of the child and documented in the form of a syllabus and learning implementation plan, (2) the implementation of PAI teaching and learning activities are implemented with a strategy diverse learning; selecting and using varied learning methods; as well as the use of learning media, (3) evaluation of Islamic Education learning outcomes for children with disabilities is carried out by using test and non-test techniques, (4) there are obstacles in learning Islamic Education with children with disabilities, namely the competence of Islamic Education teachers in presenting the learning process, supporting facilities and the lack of handbooks (textbooks) for PAI for children with disabilities so that Islamic education learning is not optimal.
\end{abstract}

Keyword: Islamic education; inclusion education; children with disabilities.

\begin{abstract}
Abstrak
Pendidikan inklusi terutama dalam mata pelajaran Pendidikan Agama Islam (PAI) merupakan sebuah konsep jaminan bagi warga negara agar mendapatkan hak pendidikan tanpa terkecuali. Penelitian ini bertujuan untuk mengetahui bagaimana manajemen pembelajaran PAI berbasis inklusi bagi anak disabilitas di Kota Makassar dengan menggunakan metode kualitatif, dan menggunakan teknik observasi, wawancara dan studi dokumentasi. Temuan dalam penelitian ini ada empat, yaitu: (1) perencanaan pembelajaran disusun oleh guru PAI yang didasarkan pada kurikulum 2013 serta disesuaikan pada karakteristik anak dan didokumentasikan dalam bentuk silabus serta rencana pelaksanaan pembelajaran, (2) pelaksanaan kegiatan belajar mengajar PAI dilaksanakan dengan strategi pembelajaran yang beragam; pemilihan dan menggunakan metode pembelajaran yang variatif; serta pemanfaatan media pembelajaran, (3) evaluasi hasil belajar PAI bagi anak disabilitas dilakukan dengan teknik tes ujian dan nontes ujian, (4) terdapat hambatan dalam pembelajaran PAI bersama anak disabilitas, yaitu belum maksimalnya kompetensi guru PAI dalam menyajikan proses pembelajaran, fasilitas penunjang dan minimnya buku pegangan (buku teks) PAI bagi anak disabilitas sehingga pembelajaran PAI belum maksimal.
\end{abstract}

Kata Kunci: pendidikan agama islam; pendidikan inklusi; anak disabilitas.

\section{A. Pendahuluan}

Eksklusifitas pendidikan merupakan salah satu problem utama dunia pendidikan. Menurut UNESCO, kecenderungan aktivitas pendidikan yang menjadi tantangan besar adalah tentang ekslusivitas pendidikan yaitu terabaikannya partisipasi dan pelaksanaan proses pendidikan dengan jumlah yang semakin bertambah, terutama anak. Diperkirakan ada sekitar 113 (seratus tiga belas) juta anak yang berasal dari berbagai negara termasuk Indonesia tidak berkesempatan untuk mendapatkan akses terhadap pendidikan, bahkan bagi negara-negara berkembang data menyebutkan angkanya mencapai $90 \%$, itu berarti hampir seluruh anak yang 
tidak mendapatkan akses pendidikan ini berasal dari negara-negara berkembang termasuk Indonesia. ${ }^{1}$ Selain itu, secara spesifik dalam data yang terangkum, masih banyak sekolahsekolah yang belum memahami manajemen pendidikan inklusi atau pemberian ruang seluasluasnya bagi anak tanpa terkecuali. Sekolah pada umumnya lebih banyak menekankan pada proses pencapaian dan peningkatan kualitas akademik anak, tanpa memperhatikan perkembangan anak dari segi sosial, spiritual dan emosionalnya. Sebagai upaya mengatasi dua tantangan tersebut, maka secara internasional terjadi sebuah perubahan paradigma dalam pendidikan yang masih bersifat konvensional (ekslusif) kedalam sebuah paradigma pendidikan yang mengutamakan akses bagi semua anak (bersifat inklusif), anti diskriminatif dan menghargai keberagaman. ${ }^{2}$

Pendidikan inklusi memiliki pengaruh besar terhadap proses pendidikan yang terjadi di dunia, setiap negara kini berlomba untuk membuat kebijakan-kebijakan maupun regulasi yang mengatur hal tersebut. Pendidikan inklusi merupakan salah satu usaha dalam pemberian akses pendidikan secara menyeluruh kepada setiap anak disabilitas dan non-disabilitas. Inklusi diartikan sebagai suatu sistem dengan menempatkan dan melibatkan kesemua elemen terkait dalam penyelenggaraan proses pendidikan, termasuk didalamnya peserta didik, tenaga kependidikan, orang tua, pengurus yayasan, guru, dan juga kepala sekolah, dengan tujuan agar bersama-sama dapat mengembangkan lingkungan pendidikan yang baik, nyaman, dan aman bagi semua anak sehingga dapat mengoptimalkan perkembangan potensi yang dimilikinya. ${ }^{3}$

Dalam melaksanakan pendidikan inklusi, proses manajemen pembelajaran menjadi salah satu faktor utama suksesnya pelaksanaan pendidikan inklusi di sekolah. Pendidik dan peserta didik secara bersinergis bersama-sama melakukan sebuah kegiatan yang dapat menciptakan iklim pembelajaran dua arah dan saling memiliki ikatan komitmen dalam mencapai sebuah tujuan dan tentunya harus tersusun dengan manajemen yang baik. Proses pembelajaran ini harus selalu dikaitkan dengan tujuan akhir pembelajaran, oleh karenanya, perencanaan dan manajemen dalam proses pembelajaran merupakan faktor penting yang harus dimaksimalkan. ${ }^{4}$

Pendidikan Agama Islam sebagai salah satu muatan wajib yang harus disajikan pada setiap jenjang pendidikan juga harus melaksanakan inklusifitas tersebut dalam proses pembelajarannya. Sebagaimana kita ketahui agama berperan sangat penting dalam hidup setiap umat manusia. Agama merupakan pokok panduan yang utama dalam usaha manusia memaknai kedamaian, kehormatan, dan martabat kehidupan yang dijalaninya. Oleh sebab itu agama tidak dapat dipisahkan dalam kehidupan, karena merupakan aspek utama pedoman manusia dalam perjalanan hidupnya. Agama menjadi penting dikarenakan menjadi pegangan dan panduan manusia dalam melewati setiap fase kehidupan. Pembelajaran Agama Islam menjadi salah satu aspek kunci dalam suksesnya manusia menjalani hidup, karena merupakan pendidikan yang diajarkan setelah pendidikan di lingkungan keluarga, maupun masyarakat. ${ }^{5}$

Pendidikan Agama Islam sangat penting untuk ditanamkan dan diaplikasikan dalam kehidupan sehari-hari setiap manusia. Allah SWT berfirman dalam QS. Al-Nahl/16: 78.

\footnotetext{
${ }^{1}$ Zaenal Alimin, "Paradigma Pendidikan Inklusif Sebagai Upaya Memperluas Akses Dan Perbaikan Mutu Pendidikan," Jurnal Asesmen Dan Intervensi Anak Berkebutuhan Khusus 12, no. 2 (2013): 171-80.

${ }^{2}$ Colette Chabbott, Constructing Education for Development, Constructing Education for Development: International Organizations and Education for All (Routledge, 2013), https://doi.org/10.4324/9780203055991.

${ }^{3}$ Sunardi Sunardi and Sunaryo Sunaryo, "Manajemen Pendidikan Inklusif," Jurnal Asesmen Dan Intervensi Anak Berkebutuhan Khusus 10, no. 2 (2011): 184-200.

${ }^{4}$ Ane Qvortrup and Lars Qvortrup, "Inclusion: Dimensions of Inclusion in Education," International Journal of Inclusive Education 22, no. $7 \quad$ (July $3, \quad 2018$ ): $803-$ 17.https://doi.org/10.1080/13603116.2017.1412506.

${ }^{5}$ Nur Ahyat, "Metode Pembelajaran Pendidikan Agama Islam," EDUSIANA: Jurnal Manajemen dan Pendidikan Islam 4, no. 1 (October 7, 2017): 24-31, https://doi.org/10.30957/edusiana.v4i1.5.
} 
Pendidikan Agama Islam dilaksanakan melalui berbagai kegiatan pengajaran, latihan, dan bimbingan dalam upaya mengembangkan pola pikir dan pola pemahaman peserta didik mengenai agamanya. ${ }^{6}$ Guru PAI memiliki peranan penting dalam menciptakan hal tersebut, karena merekalah yang berperan sebagai penghubung antara teori dan pengaplikasiannya dalam kehidupan nyata. ${ }^{7}$

Pendidikan Agama Islam berbasis inklusi sangat penting untuk menciptakan sebuah kondisi yang disebut dengan Islam sebagai rahmatan lil 'ālamīn, pembelajaran bagi anak disabilitas merupakan sebuah tantangan tersendiri karena memerlukan sebuah pendekatan khusus agar proses pembelajaran bagi anak disabilitas dapat terlaksana dengan baik dan aman. ${ }^{8}$ Pembelajaran PAI dipengaruhi oleh pengetahuan awal peserta didik yang mereka dapatkan dari keluarga di rumah, pendidikan dalam keluarga merupakan pendidikan awal yang sangat penting, karena merupakan dasar pembelajaran PAI. Pendidikan agama islam berfungsi sebagai sarana kita untuk berpikir analisis-kritis, mengembangkan kreatifitas, dan inovasi terkini dalam hal kecerdasan spiritual (spirual quotient) dan kecerdasan emosi (emotional quotient). ${ }^{9}$ bSecara umum ruang lingkup pendidikan agama Islam berhubungan dengan keserasian, keselarasan dan keseimbangan antara hubungan dirinya dengan Allah SWT, sesama manusia, diri sendiri serta makhluk dan lingkungan lainnya. ${ }^{10}$

Anak berkebutuhan khusus atau anak disabilitas sebagai bagian dari Pendidikan inklusi, masuk dalam kategori penyandang disabilitas sebagaimana tercantum dalam undang-undang Republik Indonesia nomor 8 tahun 2016 tentang penyandang disabilitas, pasal 1 menyebutkan bahwa penyandang disabilitas adalah setiap orang yang mengalami keterbatasan fisik, intelektual, mental, dan/atau sensorik dalam jangka waktu lama yang dalam berinteraksi dengan lingkungan dapat mengalami hambatan dan kesulitan untuk berpartisipasi secara penuh dan efektif dengan warga negara lainnya berdasarkan kesamaan hak. Menurut Undang-Undang Republik Indonesia nomor 8 tahun 2016 tentang penyandang disabilitas dalam pasal 4 ayat 1 ragam penyandang disabilitas meliputi: penyandang disabilitas fisik; penyandang disabilitas intelektual; penyandang disabilitas mental; dan/atau penyandang disabilitas sensorik ${ }^{11}$. Berdasarkan peraturan menteri sosial RI nomor 8 tahun 2012, maka jenis-jenis disabilitas yang terjadi pada orang dibagi menjadi tiga jenis yaitu (1) disabilitas fisik (daksa, netra dan rungu wicara); (2) disabilitas mental; dan (3) disabilitas ganda. ${ }^{12}$

Pendidikan yang diberikan kepada anak disabilitas dapat dilakukan melalui dua cara penerapan, yaitu penerapan penggabungan anak-anak non-disabilitas di sekolah reguler yang biasa dipahami sebagai pelaksanaan pendidikan inklusif, atau pendidikan khusus yang

${ }^{6} \mathrm{M}$ Sofwan Nugraha and Udin Supriadi dan Saepul Anwar, "Pembelajaran PAI Berbasis Media Digital (Studi Deskriptip Terhadap Pembelajaran PAI di SMA Alfa Centauri Bandung)," Jurnal Pendidikan Agama Islam-Ta'lim 12, no. 1 (2014): 55-67.

${ }^{7}$ M. Agus Nuryatno, "Islamic Education in a Pluralistic Society," Al-Jami'ah: Journal of Islamic Studies 49, no. 2 (December 24, 2011): 411-31, https://doi.org/10.14421/ajis.2011.492.411-431.

${ }^{8}$ Ana Rahmawati, "Konsep Pembelajaran PAI Bagi Anak Berkebutuhan Khusus di Sekolah Inklusi: Studi Kasus di SD Semai Jepara," Edukasia Islamika 3, no. 2 (December 29, 2018): 171-83, https://doi.org/10.28918/jei.v3i2.1686.

${ }^{9}$ Tony Booth and Mel Ainscow, From Them to Us: An International Study of Inclusion in Education (Psychology Press, 1998).

${ }^{10}$ Farida Isroani, "Pembelajaran Pendidikan Agama Islam Bagi Anak Berkebutuhan Khusus di Sekolah Inklusi," QUALITY 7, no. 1 (May 31, 2019): 52-53, https://doi.org/10.21043/quality.v7i1.5180.

${ }^{11}$ Undang-undang No. 8 tahun 2016 tentang Penyandang Disabilitas

12 Peraturan Menteri Sosial Republik Indonesia nomor 8 tahun 2012 
didapatkan oleh anak disabilitas, atau yang biasa disebut dengan sekolah luar biasa. ${ }^{13}$ Sistem pendidikan segregasi mengarah pada pola diskriminasi anak disabilitas dalam hal memperoleh pendidikan, karena memisahkan mereka dari teman-temannya. Pendidikan inklusi ini diharapkan dapat memaksimalkan semua potensi dan kemampuan dasar yang dimiliki oleh anak, tanpa adanya praktik diskriminasi. ${ }^{14}$ Pendidikan inklusi diterjemahkan sebagai sebuah pendekatan utama dalam pemenuhan hak-hak pendidikan dan hak-hak anak dalam proses pembelajaran atau pendidikan. ${ }^{15}$

Penelitian ini membahas tentang manajemen pembelajaran Agama Islam di sekolah inklusi, dari mulai perencanaan hingga evaluasi. Proses ini merupakan kunci ketercapaian dan keberhasilan pendidikan inklusi, sehingga diharapkan peserta didik dan pendidik juga stakeholder lainnya mampu berpikir, bekerjasama dan bertindak secara aktif dan progresif untuk menciptakan sekolah ramah disabilitas. ${ }^{16}$

Makassar adalah salah satu kota besar di Indonesia dari aspek pembangunannya dan secara demografis dengan berbagai suku bangsa yang menetap di kota ini. Selain itu Makassar terpilih menjadi KLA (Kota Layak Anak) tingkat Nindya dari Kementerian Pemberdayaan Perempuan dan Anak pada tahun $2019^{17}$, sebuah prestasi yang luar biasa dalam rangka mewujudkan suasana yang ramah bagi anak. Penelitian ini akan sangat berguna bagi pemerintah Kota Makassar agar dapat meningkatkan kualitas Pendidikan Agama Islam inklusif di Kota Makassar agar lebih maksimal, juga sebagai referensi bagi para guru bidang Agama Islam dalam melaksanakan Pendidikan inklusi di sekolah.

Berdasarkan penelusuran yang dilakukan penulis terkait dengan penelitian tentang manajemen pembelajaran PAI berbasis inklusi, penulis menemukan beberapa penelitian yang membahas hal tersebut, antara lain penelitian Nurhadisah yang berjudul "Implementasi Pendidikan Inklusi dalam Pembelajaran Pendidikan Agama Islam". ${ }^{18}$ Penelitian lain oleh Siti Auliyatus Sholawati berjudul "Manajemen Pembelajaran Pendidikan Inklusi Pada Anak Berkebutuhan Khusus di SDN Kalirungkut-1 Surabaya. ${ }^{19}$ Berdasarkan penelusuran tersebut, penelitian ini merupakan penelitian yang sudah ada, namun memiliki perbedaan dengan penelitian yang akan dilaksanakan, terutama dalam lokasi dan objek penelitian, serta pengungkapan secara menyeluruh tentang pembelajaran pendidikan Agama Islam berbasis inklusi dengan strategi (strategi blended learning) dan terapi (terapi ruang pelangi) yang ada di Kota Makassar, yang bertujuan untuk memaksimalkan potensi anak disabilitas pada sekolah-sekolah inklusi di tempat penelitian dilaksanakan.

\footnotetext{
${ }^{13}$ Eni Mariani and Bambang Suteng Sulasmono, "Evaluasi Pelaksanaan Program Pendidikan Inklusi di SMP Negeri," Kelola: Jurnal Manajemen Pendidikan 5, no. 2 (December 27, 2018): 205-16, https://doi.org/10.24246/j.jk.2018.v5.i2.p205-216.

${ }^{14}$ Rencana Induk Pengembangan Pendidikan Inklusif tingkat Nasional 2019-2024. Direktorat Pembinaan Pendidikan Khusus dan Layanan Khusus Direktorat Jenderal Pendidikan Dasar dan Menengah. Kementerian Pendidikan Dan Kebudayaan. Jakarta. 2019

${ }^{15}$ Subar Junanto and Nur Arini Asmaul Kusna, "Evaluasi Program Pembelajaran di PAUD Inklusi Dengan Model Context, Input, Process, and Product (CIPP),” INKLUSI 5, no. 2 (September 29, 2018): 179, https://doi.org/10.14421/ijds.050202.

${ }^{16}$ Sunardi and Sunaryo, "Manajemen Pendidikan Inklusif."

${ }^{17} \mathrm{https}$ ///makassarkota.go.id/komitmen-menjadikan-makassar-kota-layak-anak-iqbal-suhaeb-launchingkla diakses tanggal 20 September 202020.41 WITA

${ }^{18}$ Nurhadisah Nurhadisah, "Implementasi Pendidikan Inklusi Dalam Pembelajaran Pendidikan Agama Islam," DAYAH: Journal of Islamic Education 2, no. 2 (September 1, 2019): 201, https://doi.org/10.22373/jie.v2i2.4177.

${ }^{19}$ Siti Auliyatus Sholawati, "Manajemen Pembelajaran Pendidikan Inklusi Pada Anak Berkebutuhan Khusus di SDN Kalirungkut-1 Surabaya," Abdau: Jurnal Pendidikan Madrasah Ibtidaiyah 2, no. 1 (June 28, 2019): 39-60, https://doi.org/10.36768/abdau.v2i1.24.
} 
Pendekatan yang digunakan dalam penelitian ini adalah pendekatan kualitatif, dengan melihat social situation penelitian. Situasi sosial tersebut terdiri atas tiga elemen penting yaitu tempat (place) dimana penilitian dilakukan, pelaku (actor) atau siapa saja informan terkait penelitian, dan aktivitas (activity) aktivitas apa saja yang terjadi dalam penelitian tersebut. ${ }^{20}$ Peneliti melakukan penelitian pada 3 sekolah yang melaksanakan pendidikan inklusi di Kecamatan Panakukkang Kota Makassar yaitu Sekolah Islam Madania, Sekolah Islam AlIzhar dan Sekolah Islam Lazuardi Athaillah. Ketiga sekolah tersebut peneliti pilih sebagai lokasi penelitian karena merupakan sekolah-sekolah penyelenggara pendidikan inklusi yang lokasinya tidak jauh dari peneliti. Penelitian ini juga menggunakan metode pengumpulan data dari mulai observasi, wawancara hingga studi dokumentasi. Peneliti melaksanakan studi dokumentasi sebagai sebuah teknik dalam pengumpulan dan penelusuran berbagai data primer atau data pendukung. Penelitian merujuk kepada berbagai literatur dan hasil penelitian dari masing-masing lokus penelitian. Hal ini menunjukkan bahwa penulis dalam hal ini melaksanakan sebuah penelitian yang berlandaskan pada berbagai macam referensi berupa jurnal-jurnal ilmiah nasional maupun jurnal-jurnal ilmiah internasional yang relevan dengan judul penelitian. Metode analisis data dalam penelitian ini menggunakan metode Data Reduction, data display, dan kesimpulan. Teknik pemeriksaan data yang digunakan dalam peneliti ini adalah kredibilitas data (trianggulasi berbagai sumber dan trianggulasi berbagai teori), kemudian transferability, dan juga confirmability. ${ }^{21}$

\section{B. Temuan Penelitian}

Pendidikan Inklusi mulai terimplementasi setelah Kementerian Pendidikan dan Kebudayaan mengeluarkan sebuah peraturan menteri yaitu Permendiknas nomor 70 tahun 2009 yang dengan secara spesifik mengatur tentang berbagai hal yang berhubungan dengan pendidikan inklusi. Pasca aturan itu dikeluarkan, beberapa provinsi menerbitkan surat keputusan untuk menunjuk sekolah-sekolah umum sebagai penyelenggara pendidikan inklusi. Gubernur Sulawesi Selatan mengeluarkan surat keputusan gubernur yang menunjuk beberapa sekolah yang ada di Sulawesi Selatan menjadi pelopor pendidikan inklusi, hal ini kemudian diikuti dan dilaksanakan juga oleh beberapa kepala daerah pada tingkat kabupaten/kota, dengan membentuk banyak kelompok kerja (Pokja) yang khusus mengurus tentang pendidikan inklusi serta kebijakankebijakan terkait lainnya. Sejak dideklarasikan secara formal pada tanggal 11 Agustus 2004 dan tahun 2005 di Sulawesi Selatan, sekolah yang melaksanakan pendidikan inklusi ini kian hari semakin bertambah. Hal ini adalah pertanda positif dalam untuk meningkatkan tingkat kepedulian dan kemauan masyarakat khususnya di Sulawesi Selatan dalam upaya mewujudkan inklusifitas pendidikan di Sulawesi Selatan ${ }^{22}$.

Di Kota Makassar, ibukota Provinsi Sulawesi Selatan ${ }^{23}$, penyelenggaraan Pendidikan inklusi diatur dalam beberapa regulasi seperti UU no. 8 tahun 2016 tentang disabilitas, Pergub

\footnotetext{
${ }^{20}$ Lexy J. Moleong, Metodologi Penelitian Kualitatif, Edisi Revi (Bandung: PT. Remaja Rosda Karya, 2017).

${ }^{21}$ Moleong.

${ }^{22}$ https://www.solider.id/baca/6017-tigabelas-pendidikan-inklusi-sulawesi-selatan diakses pada tanggal 17 September 2020 pukul 06.21

${ }^{23}$ Kota Makassar adalah sebuah kota yang terletak di selatan pulau Sulawesi, pada tahun 1971 hingga 1999 kota ini dikenal sebagai Kota Ujungpandang atau Ujung pandang. Kota Makassar merupakan ibu kota Provinsi Sulawesi Selatan, kota terbesar yang merupakan etalase utama kawasan sebelah timur Indonesia yang terletak pada $5^{\circ} 8^{\prime} \mathrm{S} 119^{\circ} 25^{\prime} \mathrm{E}$ Koordinat: $5^{\circ} 8^{\prime} \mathrm{S} 119^{\circ} 25^{\prime} \mathrm{E}$, di pesisir barat daya pulau Sulawesi, berhadapan langsung dengan Selat Makassar. Kota Makassar berbatasan dengan Selat Makassar di sebelah Baratnya, kemudian Kabupaten Kepulauan Pangkajene di sebelah utaranya, Kabupaten Maros di sebelah timunrya, dan Kabupaten Gowa pada sebelah selatan. www.makassarkota.go.id diakses tanggal 15 September 2020 pukul 12.42
} 
No. 31 tahun 2011 tentang penyelenggaraan pendidikan inklusi, hingga Peraturan Daerah Kota Makassar No. 6 Tahun 2013 yang membahas secara rinci pelaksanaan Pendidikan inklusi di Kota Makassar. Pendidikan inklusi terlaksana melalui terbentuknya kelompok kerja lintas sektor yang melibatkan dinas lain di luar dinas pendidikan, selain itu beberapa Sekolah Luar Biasa (SLB) Negeri ditetapkan sebagai pusat sumber pendidikan inklusi. Secara regulasi Pendidikan inklusi di Kota Makassar sudah ideal, namun secara implementatif masih sangat jauh dari regulasi. Implementasi pendidikan inklusi seperti sekolah penyelenggara Pendidikan inklusi yang masih minim, sosialisasi inklusifitas Pendidikan yang kurang, fasilitas bagi disabilitas yang juga masih terbatas, dan implementasi pendidikan inklusi lain yang masih belum terlaksana dengan maksimal.

Pendidikan inklusi dapat diartikan sebagai strategi dan paradigma baru pembelajaran untuk mencapai titik tujuan akhir pendidikan untuk semua tanpa terkecuali. Pendidikan inklusi sebagai sebuah konsep bertujuan akhir untuk mengembangkan konsep-konsep yang koheren dan kerangka-kerangka kebijakan yang terkini dengan situasi dan kondisi pada lingkungan peserta didik baik anak disabilitas ataupun anak non-disabilitas, sehingga tercipta akses penuh dan kesamaan dalam penyelenggaraan pendidikan tanpa diskriminasi untuk semua $^{24}$. Adapun menurut guru PAI sekolah inklusi di Kota Makassar, secara umum diartikan sebagai sistem manajemen penyelenggaraan pendidikan dengan mengedepankan pemberian kesempatan yang luas bagi semua peserta didik, dalam hal ini semua anak memiliki kecerdasan dan atau bakat istimewanya masing-masing sehingga semuanya dapat mengikuti pendidikan atau pembelajaran dalam satu lingkungan pendidikan secara bersama-sama ${ }^{25}$. Definisi pendidikan inklusif, khususnya dalam proses manajemen yang dilakukan dapat juga dipahami melalui gambaran tabel 1 .

Tabel 1. Definisi Operasional Pendidikan Inklusi

\begin{tabular}{ll}
\hline Kategori & \multicolumn{1}{c}{ Definisi Operasional } \\
\hline $\begin{array}{l}\text { Cakupan / } \\
\text { Lingkup }\end{array}$ & $\begin{array}{l}\text { Lebih luas dari pada pendidikan formal, tetapi } \\
\text { mencakup rumah, masyarakat, non-formal dan sistem } \\
\text { informal }\end{array}$ \\
\hline Pola Pikir & Menghargai bahwa semua anak dapat belajar \\
& $\begin{array}{l}\text { Mengakui dan menghargai bahwa setiap anak } \\
\text { memiliki perbedaan dalam usia, jenis kelamin, etnik, } \\
\text { bahasa, disabilitas, status sosial ekonomi, potensi dan } \\
\text { kemampuan }\end{array}$ \\
\hline Pelaksanaan & $\begin{array}{l}\text { Memungkinkan struktur, sistem dan metodologi } \\
\text { memenuhi kebutuhan-kebutuhan semua anak }\end{array}$ \\
\cline { 2 - 4 } & $\begin{array}{l}\text { Merupakan proses dinamis yang secara evolusi terus } \\
\text { berkembang sejalan dengan konteks budaya }\end{array}$ \\
\hline Tujuan & $\begin{array}{l}\text { Merupakan strategi untuk memajukan dan } \\
\text { mewujudkan masyarakat inklusif }\end{array}$ \\
\hline
\end{tabular}

Sumber: Rencana Induk Pendidikan Inklusi 2019-2024

Seorang pendamping anak disabilitas menyatakan bahwa pada hakikatnya setiap anak usia sekolah termasuk anak disabilitas berhak mengikuti setiap proses dalam pembelajaran agar mendapatkan pendidikan yang berkualitas. Namun demikian, anak disabilitas

\footnotetext{
${ }^{24}$ Rencana Induk Pengembangan Pendidikan Inklusif tingkat Nasional 2019-2024. Direktorat Pembinaan Pendidikan Khusus Dan Layanan Khusus Direktorat Jenderal Pendidikan Dasar dan Menengah. Kementerian Pendidikan dan Kebudayaan. Jakarta. 2019.

${ }^{25}$ Wawancara dan diskusi Bersama guru PAI
} 
membutuhkan beberapa perlakukan dan penanganan khusus karena kedisabilitasannya sehingga memerlukan pendamping khusus. Dalam pelaksanaan pendidikan inklusi ini, manajemen pendidikan menjadi faktor penting lainnya dalam penyusunan pola belajar dan mengajar, agar terciptanya pembelajaran yang aman, nyaman, efisien dan efektif. Sekolahsekolah inklusi di Kota Makassar melaksanakan manajemen pendidikan tersebut dalam kurikulum yang dibagi dalam tiga tahapan, yaitu rencana pembelajaran di awal, kegiatan atau pelaksanaan pembelajaran dan penilaian hasil belajar atau evaluasi di akhir ${ }^{26}$.

\section{B.1. Perencanaan Pembelajaran PAI Berbasis Inklusi bagi Anak Disabilitas}

Tujuan pembelajaran dalam pelaksanaannya secara umum dikategorikan kedalam tiga jenis kemampuan (ability), yaitu kemampuan kognitif, afektif, dan psikomotor. Tujuan pendidikan ada yang merupakan tujuan nasional hingga tujuan tingkat institusi, tujuan yang paling penting untuk diperhatikan dan dipahami oleh pendidik adalah tujuan pendidikan pada level institusi (tujuan lembaga/ institusional) serta tujuan instruksional pembelajaran. ${ }^{27}$ Perencanaan pembelajaran menjadi pendorong utama efektifitas dan efisiensi pelaksanaan pembelajaran Pendidikan agama Islam berbasis inklusi. Sebagaimana yang disampaikan oleh UT salah seorang guru PAI di SMP Madania Kota Makassar:

“...Perencanaan menjadi elemen kunci dalam menentukan pola dan tujuan akhir pembelajaran. Koordinasi dan konsultasi dari seluruh pihak terkait akan menumbuhkan keselerasan tersebut, sehingga tujuan-tujuan yang telah ditentukan dapat terlaksana dengan maksimal" 28 .

Perencanaan yang dilakukan oleh sekolah-sekolah inklusi dilaksanakan dalam sebuah pertemuan antara kepala sekolah, wakil kepala bidang kurikulum, guru beserta pendamping disabilitas sekolah ${ }^{29}$. Kurikulum 2013 adalah kurikulum yang digunakan oleh tiga sekolah dalam menjalankan proses pembelajarannya, dengan beberapa penyesuaian dalam implementasi pendidikan inklusi di sekolahnya. Jika dikaitkan dengan kurikulum yang digunakan oleh ketiga sekolah tempat penelitan yaitu kurikulum 2013, maka yang dimaksud dengan tujuan pendidikan atau pembelajaran kurang lebih sama dengan apa yang disebut dalam kompetensi inti, kompetensi dasar dan indikator. Sehingga terdapat empat jenis kompetensi dalam kurikulum yang dilaksanakan, yang harus diperhatikan oleh pendidik kaitannya dengan tujuan akhir pembelajaran dalam setting inklusi, yaitu: Standar kompetensi lulusan (SKL); Kompetensi Inti (KI); Kompetensi Dasar (KD) dan Indikator keberhasilan. ${ }^{30}$

Implementasi manajemen pembelajaran PAI bagi anak disabilitas di sekolah inklusi SMP Madania, Al-Izhar dan Lazuardi Kota Makassar adalah dengan menyusun rencana pembelajaran PAI bagi anak disabilitas dengan menyusun RPP yang dimusyawarahkan dengan komite sekolah maupun dengan orang tua peserta didik tentang layanan yang akan diterima oleh peserta didik. Setelah itu anak diberikan tes IQ, dan asesmen. Hasil dari tes dan asesmen itulah yang dijadikan dasar untuk menentukan pendekatan pembelajaran dan layanan yang akan diterima oleh anak. Sebagaimana pernyataan guru PAI dari SMP Lazuardi UZ:

\footnotetext{
${ }^{26}$ Wawancara dan diskusi bersama CR seorang guru pendamping khusus.

${ }^{27}$ Sari Rudiyati, "Substansi Komponen Kompetensi Guru Sekolah Inklusif Bagi Anak Berkelainan/Berkebutuhan Pendidikan Khusus," Jurnal Penelitian Dan Evaluasi Pendidikan 16, no. 2 (January 14, 2013): 533-52, https://doi.org/10.21831/pep.v16i2.1130.

${ }^{28}$ Wawancara dan diskusi bersama UT seorang guru PAI

${ }^{29}$ Hasil wawancara dengan guru agama Islam UZ \& PA

${ }^{30}$ Indah Permata Darma and Binahayati Rusyidi, "Pelaksanaan Sekolah Inklusi di Indonesia," Prosiding Penelitian dan Pengabdian Kepada Masyarakat 2, no. 2 (October 1, 2015): 223-27, https://doi.org/10.24198/jppm.v2i2.13530.
} 
"tes IQ dan asesmen sangatlah penting karena melalui proses tersebut guru dapat merencanakan pembelajaran yang sesuai. Jadi, melalui beberapa langkah tadi guru tidak sembarangan dalam memberikan pembelajaran bagi anak disabilitas" 31 .

Pengembangan kurikulum adaptif yang dilaksanakan merupakan penyesuaian kurikulum bagi anak-anak dengan kedisabilitasan. Dalam pelaksanaannya anak disabilitas yang mengikuti pendidikan pada sekolah-sekolah inklusi secara umum mendapatkan penyesuaian kurikulum tersebut dengan empat model pengembangan kurikulum adaptif yang berbeda-beda, yaitu: (1) model duplikasi; (2) model modifikasi; (3) model subtitusi, dan (4) model omisi. Secara umum SMP Madania, SMP Lazuardi Athaillah dan SMP Al-Izhar Makassar melaksanakan keempat pilihan pengembangan kurikulum adaptif, contohnya dengan mengikuti kurikulum yang ada yaitu kurikulum 2013, perumusan kurikulum berdasarkan tujuan, isi, proses dan evaluasi, termasuk dengan Standar Kompetensi Lulusan (SKL), Kompetensi Inti (KI), dan Kompetensi Dasar (KD). Secara model modifikasi, misalnya dengan pengembangan 18 karakter dalam permendikbud menjadi 20 karakter. Secara model substitusi, dilaksanakan misalnya dengan mengganti praktek dalam kurikulum seperti praktek sholat, mengaji dan menghafal surat-surat pendek dan doa-doa, yang disesuaikan dengan kemampuan dan kebutuhan. Secara model omisi, dilaksanakan dengan menghapuskan beberapa kurikulum yang cenderung memberatkan peserta didik khususnya bagi anak disabilitas. Penyesuaian ini juga berlaku dalam proses-proses pembelajaran khusus, seperti anak dengan kedisabilitasan fisik memiliki keterbatasan dalam persepsi motorik dalam ibadah, sehingga pelajaran sholat atau ibadah lainnya dapat diadaptasi dan disesuaikan dengan kondisi yang ada ${ }^{32}$.

\section{B.2. Pelaksanaan Manajemen Pembelajaran PAI}

Kota Makassar sebagai Kota Layak Anak tingkat Nindya terus berusaha untuk menunjukan kelayakannya sebagai kota layak anak dengan memperbanyak sekolah inklusi, walaupun dalam pelaksanaannya masih banyak terjadi penolakan yang disebabkan oleh ketidakpahaman masyarakat tentang pendidikan inklusi. Pihak sekolah banyak yang beralibi bahwa kebijakan pendidikan inklusi itu bukan ditujukan pada peserta didik dengan kedisabilitasan fisik secara umum, melainkan ditujukan kepada kedisabilitasan fisik yang bersifat semi permanen. ${ }^{33}$ Di Kecamatan Panakukang terdapat 6 anak disabilitas yang mendapatkan Pendidikan inklusi ${ }^{34}$, sebagaimana dijelaskan dalam tabel 2.

Tabel 2. Data Jumlah Anak Disabilitas pada Sekolah Inklusi di Kecamatan Panakukang

\begin{tabular}{ccccc}
\hline No. & $\begin{array}{c}\text { Jenjang } \\
\text { Sekolah }\end{array}$ & $\begin{array}{c}\text { Jenis } \\
\text { Kedisabilitasan }\end{array}$ & $\begin{array}{c}\text { Jumlah } \\
\text { Anak }\end{array}$ & $\begin{array}{c}\text { Kategori } \\
\text { Sekolah }\end{array}$ \\
\hline $\mathbf{1}$ & SD & - & - & - \\
\hline $\mathbf{2}$ & SMP & Disabilitas Intlektual & 4 & Swasta \\
\hline $\mathbf{3}$ & SMP & Disabilitas Fisik & 2 & Swasta \\
\hline
\end{tabular}

Sumber: Data Primer Penelitian

\footnotetext{
${ }^{31}$ Hasil wawancara dengan Guru Agama Islam (UZ). 20 Agustus 2020

${ }^{32}$ Hasil wawancara dengan Guru Agama Islam (UZ). 20 Agustus 2020

${ }^{33} \mathrm{https}: / / \mathrm{www}$. solider.id/baca/6017-tigabelas-pendidikan-inklusi-sulawesi-selatan diakses pada tanggal 17 september 2020 pukul 06.21 WITA

${ }^{34}$ Data hasil studi dokumentasi pada sekolah-sekolah inklusi di Kecamatan Panakukkang Kota Makassar
} 
Dalam pelaksanaan manajemen pembelajaran PAI, SMP Lazuardi juga menjadwalkan sebuah terapi untuk mensukseskan pendidikan inklusi yang dilakukan, yaitu dengan terapi Pelangi Lazuardi. Ini merupakan praktek layanan terapi sensori integrasi dan okupasi terapi bagi anak-anak yang membutuhkan penanganan khusus, bertujuan untuk membantu anak melatih konsentrasi/fokus, keseimbangan diri, dan skill atau kemampuan yang harus dimiliki sesuai dengan usia perkembangan anak. Kegiatan ini didampingi oleh psikolog anak dan fisioterapis Ruang Pelangi Lazuardi dilaksanakan setiap hari senin, selasa dan jumat dari pukul 14.00 hingga pukul $16.00 \mathrm{WIB}^{35}$.

Kegiatan teletarapi yang dilakukan mencakup beberapa kategori, yaitu pertama, sensory regulation, sebuah terapi yang berfokus pada kegiatan penguatan sensori anak. Hal ini tentunya harus didukung oleh keluarga peserta didik agar pelaksanaannya dapat lebih maksimal. Kedua, fine and gross motor skills, sebuah terapi yang berfokus pada kegiatan motoric peserta didik, khususnya anak dengan kediabilitasan. Ketiga, visual motor skills, sebuah terapi yang berfokus pada aktivitas visual peserta didik, khususnya visual yang dihubungkan dengan aktivitas motorik peserta didik. Keempat, school-related self-care skills, bentuk terapi yang befokus pada perwatan diri anak disabilitas sehingga dapat melaksanakan tugas dan peran dalam perawatan diri secara mandiri. Kelima, speech-language program, sebuah bentuk terapi yang difokuskan pada kemampuan berbicara dan berbahasa peserta didik. ${ }^{36}$.

Anak disabilitas dalam mengikuti rangkaian proses pembelajaran dapat diikutsertakan dalam beberapa contoh model layanan Pendidikan inklusi, seperti model regular (inklusi penuh) yaitu anak disabilitas mengikuti proses belajar bersama anak-anak lainnya tanpa batas, dan dengan input/output kurikulum yang sama; Model kelas reguler dengan cluster yaitu dimana anak disabilitas mengikuti rangkaian proses pembelajaran bersamaan dengan anakanak lain, namun ditempatkan pada kelompok kecil atau kelompok khusus; Model kelas reguler dengan pull out yaitu dimana anak disabilitas mengikuti seluruh proses pembelajaran bersamaan dengan anak lainnya, namun dalam waktu-waktu tertentu secara terjadwal, mereka belajar pada ruang sumber tersendiri untuk mengikuti proses pembelajaran bersama guru pembimbing khusus (GPK); Model kelas reguler dengan cluster dan pull out yaitu dimana anak disabilitas mengikuti seluruh rangkaian proses pembelajaran Bersama anak lainnya pada kelas reguler yang dikelompokan secara khusuus, namun dalam beberapa waktu-waktu tertentu secara terjadwal belajar terpisah di ruang sumber bersama guru pembimbing khusus; Model kelas yang dibuat khusus dengan berbagai proses sistem pengintegrasian yaitu dimana anak disabilitas secara umum belajar di dalam kelas khusus pada penyelenggaraan sekolah reguler, namun dijadwalkan dalam beberapa bidang-bidang tertentu dapat mengikuti proses pembelajaran Bersama anak non-disabilitas lainnya; dan model kelas khusus penuh, yaitu dimana anak disabilitas yang belajar di dalam kelas khusus pada sekolah reguler. ${ }^{37}$

Model layanan Pendidikan inklusi yang digunakan di tiga sekolah inklusi di Kota Makassar menggunakan model kelas reguler dengan pull out. CR menyetakan:

"hal ini dimaksudkan agar anak dapat lebih banyak bersosialisasi dengan anak-anak lainnya, selain itu kedisabilitasan anak yang bersifat mental dan fisik hanya datang sesekali sehingga, pemisahan proses pembelajaran juga dilakukan sesekali. Anak berkebutuhan khusus atau anak disabilitas tidak selamanya mengikuti proses pembelajaran di kelas bersama teman-temannya, terlebih dalam masa pandemi covid-19 guru pendamping dan

${ }^{35}$ Hasil wawancara dengan Guru Pendamping Khusus (CR). 20 Agustus 2020

${ }^{36}$ Hasil wawancara dengan Guru Pendamping Khusus (CR). 20 Agustus 2020

${ }^{37}$ Achmad Dahlan Muchtar, "Implementasi Kurikulum PAI 2013 Pada Anak Berkebutuhan Khusus di SMPLB Bhakti Kencana Yogyakarta,” Edumaspul - Jurnal Pendidikan 2, no. 1 (February 28, 2018): 70-78, https://doi.org/10.33487/edumaspul.v2i1.16. 
guru agama islam memberikan proses pembelajaran yang terpisah dikarenakan anak sulit untuk fokus jika menggunakan sistem belajar daring. Namun, dalam konsep sekolah inklusi yang ideal hendaknya waktu anak disabilitas lebih banyak di ruangan kelas reguler, apalagi jika anak baru bertemu dengan teman-temannya".

"Pelaksanaan pembelajaran di masing-masing sekolah juga didukung dengan adanya layanan terapi yang disediakan dan diberikan oleh sekolah kepada anak disabilitas, sehingga dapat mempercepat proses sosialisasi dan adaptasi anak terhadap lingkungan barunya. Kolaborasi antara kepala sekolah, guru, staf, pendamping dan orang tua juga harus konsistensi dan berkomitmen tinggi dalam melaksanakan dukungan keberhasilan pendidikan inklusi ini. Komitmen pendidik dalam mendidik setiap peserta didiknya harus kuat karena merupakan tugas mulia untuk mencerdaskan kehidupan bangsa" ${ }^{\text {"38 }}$.

Dalam pelaksanaan pembelajaran khusunya agama islam, peserta didik memerlukan rangkaian terapi yang dapat mengembalikan fokus dan melatih kesiapan anak disabilitas dalam mengikuti pembelajaran, apalagi sekolah-sekolah islam terpadu ini menerapkan paradigma pendidikan modern berdasar hasil penelitian mutakhir seperti teori Multipe Intelligences yang dipopulerkan Howard Gardner, Brain Based Teaching (BBT), Project Based Learning (PBL), dan Authentic Assessment. Setiap anak sangat didorong untuk berupaya membentuk pengetahuan mereka sendiri berdasarkan pengalaman nyata (Contextual Teaching and Learning) dan praktek langsung berdasarkan masalah (Problem Based Learning). Sebagaimana prinsip individualisasi, bahwa anak memiliki keunikannya masingmasing sehingga kita sebagai pendidik tidak bisa meyamaratakan semuanya. Guru Agama Islam berperan sebagai fasilitator dengan memberikan tantangan-tantangan kreatif kepada peserta didik, juga sebagai katalisator untuk memantik kreativitas peserta didik dari beragam metode belajar, baik visual, auditori maupun konkret kinestetik. Peran keluarga juga sangat berperan penting dalam menjaga resiliensi anak dalam mengikuti proses Pendidikan inklusi. ${ }^{39}$

Selain itu, peran terapis juga sangat penting dalam Pendidikan inklusi, kegiatankegiatan terapi yang dilakakukan seperti (1) Sensory regulation, (2) Fine and gross motor skills. (3)Visual motor skills. (4) School-related self-care skills. (5) Speechlanguage Program. Menurut CR, untuk anak dengan jenis kedisabilitasan mental seperti F \& $\mathrm{K}$, pendidik harus dapat menyatu dengan anak disabilitas, hal ini karena $\mathrm{F} \& \mathrm{~K}$ memiliki sensitifitas yang tinggi, sehingga apabila kita tidak memperhatikan atau tidak mendengarkan ceritanya, anak akan tiba-tiba marah, selain itu metode belajar yang variatif juga sangat mendukung proses pembelajaran, sehingga ketika anak mulai tidak fokus, guru dapat mengembalikan fokusnya terlebih dahulu dengan bermain atau metode pembelajaran aktif seperti memberikan cerita dalam menjelaskan materi. Sikap dan kebiasaan anak dengan kedisabilitasan mental (autism dan asperger) yang cerewet dan lebih atraktif, membuat guru harus siap dengan segala kondisi dan situasi, sehingga behaviour control anak dapat terjaga dan fokus terhadap proses pembelajaran ${ }^{40}$.

Guru juga harus selalu siap diluar pelaksanaan pembelajaran di sekolah, tak jarang anak menelpon guru untuk sekadar menanyakan kabar, berbincang, hingga curhat kepada guru. F bahkan mengaku selalu senang jika diperhatikan dan diajak berbicara. Secara motorik anak juga berkembang dengan baik, shalat sesuai dengan seharusnya, bacaan sholat sudah hafal walau kadang lupa, hal ini juga dilakukannya dirumah, anak juga melaksanakan kewajibannya untuk shalat, dan mengaji ${ }^{41}$. Orangtua sangat senang dengan sistem Pendidikan

\footnotetext{
${ }^{38}$ Wawancara dengan CR guru pendamping khusus

${ }^{39}$ Rd. Zaky Miftahul Fasa, "Resiliensi Keluarga Korban Bencana Longsor di Kecamatan Cimenyan Kabupaten Bandung,” Jurnal Mimbar Kesejahteraan Sosial 2, no. 1 (2019): 1-11.

${ }^{40}$ Wawancara dengan CR guru pendamping khusus

${ }^{41}$ Wawancara dengan UZ guru Agama Islam.
} 
inklusi, karena hal ini dapat memberikan ruang bagi orangtua yang memiliki anak seperti mereka. Ditanya tentang alasan, Orangtua menyekolahkan anaknya di sekolah umum dengan alasan tidak ingin memperparah situasi anaknya stagnan di satu frame, mereka ingin anaknya bersosialisasi dan bergaul dengan teman lainnya, meningkatkan kepercayaan diri, dan mensosialisasikan kedisabilitasan dan inklusifitas, mereka percaya bahwa anak-anak mereka memiliki kemampuan dan prestasi akademis yang dapat bersaing dengan teman-teman seusianya ${ }^{42}$.

Secara perkembangan, anak penyandang disabilitas seperti $\mathrm{F}$ dan $\mathrm{K}$ sebenarnya memiliki kemampuan nalar dan pola pikir yang baik, hal ini terlihat dari kemampuan anak untuk mengikuti proses pembelajaran seperti praktik shalat, mengaji hingga menghafal suratsurat pendek. Beberapa anak disabilitas yang belajar di sekolah inklusi memiliki kemampuan pemahaman belajar yang baik secara akademik, sehingga harus didukung dengan lingkungan sekolah yang positif agar anak berkebutuhan khusus ini dapat terus berkembang dan beradaptasi dengan baik terhadap lingkungannya. Hal ini sangat berpengaruh karena 2 anak disabilitas yang belajar di sekolah inklusi pernah sekolah di salahsatu sekolah unggulan, namun karena terlalu banyak mendapatkan perundungan, sehingga orangtua memutuskan untuk memindahkannya di sekolah lain ${ }^{43}$.

Dalam praktiknya, manajemen pembelajaran PAI dan guru pendamping sangat dibutuhkan dalam mensukseskan pelaksanaan pendidikan inklusi di sekolah, sebagaimana yang juga disampaikan oleh CR:

“... implementasi pendidikan inklusi seharusnya bukan menyamaratakan anak disabilitas dengan anak-anak lainnya, dibutuhkan penyesuaian kurikulum, asesmen dan capaian kompetensi anak berkebutuhan khusus. Penyamarataan kurikulum, sistem asesmen, dan capaian kompetensi bagi anak disabilitas menimbulkan tuntutan berlebih bagi anak yang berpotensi mengganggu psikis anak berkebutuhan khusus yang sensitif, atau permakluman guru yang berlebih sehingga tidak mencapai standar kompetensi yang telah disusun. Selanjutnya dibutuhkan pendampingan awal sejak pertama kali masuk di sekolah inklusi oleh seorang pendamping yang memiliki keterampilan dalam membimbing anak dengan kedisabilitasan agar dapat cepat beradaptasi dan bersosialisasi dengan anak-anak lainnya" 44.

\section{B.3. Evaluasi Hasil Pembelajaran PAI Berbasis Inklusi}

Standar kompetensi yang telah ditentukan merupakan tujuan utama dalam output hasil pembelajaran PAI. Hasil penelitian menyebutkan bahwa evaluasi pembelajaran PAI berbasis inklusi yang dilakukan di SMP Al-Izhar, Madania, dan Lazuardi Athillah disesuaikan dengan jenis kedisabilitasan dari masing-masing peserta didik, hal ini menjadi penting dan harus diperhatikan karena dalam proses evaluasi pembelajaran, para anak disabilitas memiliki perbedaan karakteristik, kemampuan, intelektualitas, emosional, fisik, dan etika. Evaluasi pembelajaran yang bersifat umum dilaksanakan secara bersamaan dengan peserta didik lainnya, namun evaluasi-evaluasi pembelajaran tertentu seperti dalam praktek mengaji dan praktek ibadah lainnya para anak disabilitas memiliki waktu khusus bersama guru PAI nya. Faktor-faktor seperti perbedaan karakteristik, kemampuan, intelektualitas, emosional, fisik, dan etika sebagaimana dimaksud menunjukan proses evaluasi pembelajaran PAI berbasis inklusi menganut prinsip belajar yang fleksibel. Evaluasi yang dilakukan diketiga sekolah tersebut dilaksanakan terintegrasi namun terpisah dalam beberapa hal yang bersifat praktek.

\footnotetext{
${ }^{42}$ Wawancara dengan $(\mathrm{R})$ orang tua anak disabilitas di sekolah inklusi

${ }^{43}$ Hasil wawancara dengan Guru Pendamping Khusus (CR). 20 Agustus 2020

${ }^{44}$ Hasil wawancara dengan Guru Pendamping Khusus (CR). 20 Agustus 2020
} 


\section{B.4. Kendala dan Upaya yang Dilakukan dalam Pembelajaran PAI di Sekolah Inklusi.}

Ada beberapa kendala dalam pembelajaran PAI di sekolah inklusi Kota Makassar. Pertama, anak berkebutuhan khusus memerlukan pendekatan emosi yang kuat (engagement) sebelum memulai proses pembelajaran, agar anak dapat mengikuti proses pembelajaran dengan baik. Kedua, anak berkebutuhan khusus di sekolah inklusi terlalu banyak menerima materi mengikuti kurikulum yang berlaku di sekolah, sedangkan anak disabilitas memiliki kesulitan untuk fokus dalam waktu yang lama, diperlukan kreativitas guru untuk dapat mengembalikan fokus anak diabilitas mental. Ketiga, kapasitas guru Agama Islam perlu ditingkatkan melalui berbagai pelatihan-pelatihan terkait kedisbilitasan dan pendidikan inklusi ${ }^{45}$. Untuk meminimalisir kendala tersebut, sekolah-sekolah inklusi di Kecamatan Panakukkang Kota Makassar memiliki pertemuan dan pelatihan rutin setiap pekan bagi para pendamping dan guru. Pada pertemuan tersebut dibahas tentang terapi bagi anak, pendampingan, engagement, peningkatan kapasitas guru inklusi, dan materi-materi lain terkait pendidikan inklusi. Narasumber atau fasilitatornya berasal dari konsultan anak disabilitas untuk pendidikan dari Jakarta ${ }^{46}$.

Pelatihan, peningkatan fasilitas dan koordinasi menjadi kunci dalam manajemen pembelajaran PAI bagi anak disabilitas. Sebagaimana yang disampaikan oleh Kepala Sekolah SMP Lazuardi Makassar AH

"..dibutuhkan pelatihan-pelatihan secara intensif, pendamping anak juga diharapkan benarbenar lulusan S1 Pendidikan Luar Biasa agar dalam melakukan proses pembelajaran bisa lebih maksimal dalam mendampingi anak disabilitas, kemudian peneingkatan fasilitasfasilitas seperti guiding block, ruang khusus terapi, buku-buku braile, serta fasilitasfasilitas lainnya"47.

\section{Penutup}

Manajemen pembelajaran PAI bagi anak disabilitas pada sekolah inklusi merupakan sebuah keniscayaan, karena merupakan ujung tombak kesuksesan pelaksanaan Pendidikan inklusi pada suatu sekolah. Maka manajemen pembelajaran Pendidikan agama islam yang telah dilaksanakan oleh tiga sekolah yaitu SMP Madania, SMP Al-Izhar dan SMP Lazardi dapat dijadikan rujukan dalam pelaksanaan Pendidikan inklusi secara umum. Pendidikan Inklusi sudah lama didiskusikan, namun masih sebatas kebijakan dan diskusi, tidak terimplementasi dan terlaksana sebagaimana mestinya. Peneliti berharap bahwa Kota Makassar bahkan Sulawesi Selatan bukan hanya memiliki beragam regulasi tentang pendidikan inklusi, namun dapat mengimplementasikannya dengan maksimal. Pendidikan berbasis inklusi itu adalah sebuah proses, yang harus dilihat sebagai sebuah pencarian tanpa akhir untuk menemukan konsep nyata hadirnya pendidikan bagi semua tanpa terkecuali. Untuk itu, semua harus dimulai dengan mainstreaming pendidikan inklusi itu sendiri. Peneliti meyakini dengan semakin banyaknya sekolah yang melaksanakan Pendidikan inklusi bersama anak-anak disabilitas dengan keberaniannya keluar dari zona nyaman sekolah luar biasa ke sekolah umum, merupakan sebuah proses penting dari implementasi pendidikan inklusi agar dapat dilaksanakan dengan maksimal.

Kesimpulan dari penelitian ini yaitu: (1) perencanaan pembelajaran disusun oleh guru PAI yang didasarkan pada kurikulum 2013 serta disesuaikan pada karakteristik anak dan didokumentasikan dalam bentuk silabus serta rencana pelaksanaan pembelajaran, (2) pelaksanaan kegiatan belajar mengajar PAI dilaksanakan dengan strategi pembelajaran yang beragam; pemilihan dan menggunakan metode pembelajaran yang variatif; serta pemanfaatan

\footnotetext{
${ }^{45}$ Wawancara dengan CR Guru Pendamping Khusus

${ }^{46}$ Wawancara dengan CR Guru Pendamping Khusus

${ }^{47}$ Wawancara dengan AH Kepala Sekolah SMP Lazuardi Makassar
} 
media pembelajaran, (3) evaluasi hasil belajar PAI bagi anak disabilitas dilakukan dengan teknik tes ujian dan nontes ujian, (4) terdapat hambatan dalam pembelajaran PAI bersama anak disabilitas, yaitu belum maksimalnya kompetensi guru PAI dalam menyajikan proses pembelajaran, fasilitas penunjang dan minimnya buku pegangan (buku teks) PAI bagi anak disabilitas sehingga pembelajaran PAI belum maksimal.

\section{DAFTAR PUSTAKA}

Ahyat, Nur. "Metode Pembelajaran Pendidikan Agama Islam." EDUSIANA: Jurnal Manajemen dan Pendidikan Islam 4, no. 1 (October 7, 2017): 24-31. https://doi.org/10.30957/edusiana.v4i1.5.

Alimin, Zaenal. "Paradigma Pendidikan Inklusif Sebagai Upaya Memperluas Akses Dan Perbaikan Mutu Pendidikan." Jurnal Asesmen dan Intervensi Anak Berkebutuhan Khusus 12, no. 2 (2013): 171-80.

Booth, Tony, and Mel Ainscow. From Them to Us: An International Study of Inclusion in Education. Psychology Press, 1998.

Chabbott, Colette. Constructing Education for Development. Constructing Education for Development: International Organizations and Education for All. Routledge, 2013. https://doi.org/10.4324/9780203055991.

Darma, Indah Permata, and Binahayati Rusyidi. "Pelaksanaan Sekolah Inklusi di Indonesia." Prosiding Penelitian dan Pengabdian Kepada Masyarakat 2, no. 2 (October 1, 2015): 223-27. https://doi.org/10.24198/jppm.v2i2.13530.

Fasa, Rd. Zaky Miftahul. "Resiliensi Keluarga Korban Bencana Longsor di Kecamatan Cimenyan Kabupaten Bandung." Jurnal Mimbar Kesejahteraan Sosial 2, no. 1 (2019): $1-11$.

Isroani, Farida. "Pembelajaran Pendidikan Agama Islam Bagi Anak Berkebutuhan Khusus di Sekolah Inklusi." QUALITY 7, no. 1 (May 31, 2019): 52-53. https://doi.org/10.21043/quality.v7i1.5180.

Junanto, Subar, and Nur Arini Asmaul Kusna. "Evaluasi Program Pembelajaran di PAUD Inklusi Dengan Model Context, Input, Process, and Product (CIPP)." INKLUSI 5, no. 2 (September 29, 2018): 179. https://doi.org/10.14421/ijds.050202.

Mariani, Eni, and Bambang Suteng Sulasmono. "Evaluasi Pelaksanaan Program Pendidikan Inklusi di SMP Negeri." Kelola: Jurnal Manajemen Pendidikan 5, no. 2 (December 27, 2018): 205-16. https://doi.org/10.24246/j.jk.2018.v5.i2.p205-216.

Moleong, Lexy J. Metodologi Penelitian Kualitatif. Edisi Revisi. Bandung: PT. Remaja Rosda Karya, 2017.

Muchtar, Achmad Dahlan. "Implementasi Kurikulum PAI 2013 Pada Anak Berkebutuhan Khusus Di SMPLB Bhakti Kencana Yogyakarta.” Edumaspul - Jurnal Pendidikan 2, no. 1 (February 28, 2018): 70-78. https://doi.org/10.33487/edumaspul.v2i1.16.

Nurhadisah, Nurhadisah. "Implementasi Pendidikan Inklusi dalam Pembelajaran Pendidikan Agama Islam.” DAYAH: Journal of Islamic Education 2, no. 2 (September 1, 2019): 201. https://doi.org/10.22373/jie.v2i2.4177.

Nuryatno, M. Agus. "Islamic Education in a Pluralistic Society." Al-Jami'ah: Journal of Islamic Studies 49, no. 2 (December 24, 2011): 411-31. https://doi.org/10.14421/ajis.2011.492.411-431.

Qvortrup, Ane, and Lars Qvortrup. "Inclusion: Dimensions of Inclusion in Education." International Journal of Inclusive Education 22, no. 7 (July 3, 2018): 803-17. https://doi.org/10.1080/13603116.2017.1412506.

Rahmawati, Ana. "Konsep Pembelajaran PAI Bagi Anak Berkebutuhan Khusus di Sekolah Inklusi: Studi Kasus di SD Semai Jepara.” Edukasia Islamika 3, no. 2 (December 29, 2018): 171-83. https://doi.org/10.28918/jei.v3i2.1686. 
Rudiyati, Sari. "Substansi Komponen Kompetensi Guru Sekolah Inklusif Bagi Anak Berkelainan/Berkebutuhan Pendidikan Khusus." Jurnal Penelitian Dan Evaluasi Pendidikan 16, no. 2 (January 14, 2013): 533-52. https://doi.org/10.21831/pep.v16i2.1130.

Sholawati, Siti Auliyatus. "Manajemen Pembelajaran Pendidikan Inklusi Pada Anak Berkebutuhan Khusus di SDN Kalirungkut-1 Surabaya." Abdau: Jurnal Pendidikan Madrasah Ibtidaiyah 2, no. 1 (June 28, 2019): 39-60. https://doi.org/10.36768/abdau.v2i1.24.

Sofwan Nugraha, M, and Udin Supriadi dan Saepul Anwar. "Pembelajaran PAI Berbasis Media Digital (Studi Deskriptip Terhadap Pembelajaran PAI di SMA Alfa Centauri Bandung)." Jurnal Pendidikan Agama Islam -Ta'lim 12, no. 1 (2014): 55-67.

Sunardi, Sunardi, and Sunaryo Sunaryo. "Manajemen Pendidikan Inklusif." Jurnal Asesmen dan Intervensi Anak Berkebutuhan Khusus 10, no. 2 (2011): 184-200. 